Original Research Paper

\title{
Pelatihan Rancang Bangun Alat Deteksi Kelelahan Berbasis Audiovisual untuk Meningkatkan Kualitas Kerja Dan Kesehatan di SMK 3 Pancasila Kecamatan Ambulu Kabupaten Jember Provinsi Jawa Timur
}

\author{
Khusnul Ain $^{1^{*}}$, Riries Rulaningtyas ${ }^{1}$, Alfian Pramudita Putra ${ }^{1}$ \\ ${ }^{I}$ Teknik Biomedis, Universitas Airlangga, Surabaya, Indonesia
}

https://doi.org/10.29303/jpmpi.v3i2.594

Sitasi: Ain, K., Rulaningtyas, R., \& Putra, A. P. (2021). Pelatihan Rancang Bangun Alat Deteksi Kelelahan Berbasis Audiovisual untuk Meningkatkan Kualitas Kerja Dan Kesehatan di SMK 3 Pancasila Kecamatan Ambulu Kabupaten Jember Provinsi Jawa Timur. Jurnal Pengabdian Magister Pendidikan IPA, 4(1)

\author{
Article history \\ Received: 02 Desember 2020 \\ Revised: 29 Desember 2020 \\ Accepted: 19 Januari 2021 \\ *Corresponding Author: \\ Khusnul Ain, Teknik \\ Biomedis, Universitas \\ Airlangga, Surabaya, Indonesia \\ Email: $\underline{\text { __ain@fst.unair.ac.id }}$
}

\begin{abstract}
Kelelahan adalah salah satu permasalahan serius yang sering dialami pekerja sehingga bisa mengancam nyawa jika kurang mendapat perhatian. Organisasi Buruh Dunia melaporkan sebanyak 2 juta/tahun pekerja melayang nyawanya akibat kecelakaan kerja yang disebabkan oleh kelelahan. Di Indonesia jumlah kecelakaan kerja mengalami peningkatan tiap tahunnya hingga 5\%. Data dari BPJS ketenagakerjaan menunjukkan bahwa pada tahun 2016 terjadi 116.850 kasus kecelakaan kerja sedangkan pada tahun 2017 jumlah kasus meningkat menjadi 123.000 kasus. Banyak penelitian menunjukkan bahwa kelelahan adalah salah satu faktor yang berkontribusi sebagai penyebab kecelakaan. Salah satu cara untuk mengurangi resiko tersebut adalah mengukur kelelahan yang dialami pekerja. Kelelahan dapat dideteksi dengan mengukur waktu respon terhadap rangsangan yang diberikan. Waktu respon umpan balik sebagai tanggapan dari rangsangan yang diberikan merupakan parameter utama yang digunakan untuk menentukan tingkat kelelahan seseorang. Berdasarkan analisis situasi tersebut, maka melalui kegiatan pengabdian masyarakat Program Kemitraan Masyarakat ini, dapat diberikan bekal keahlian kepada siswa Sekolah Menengah Kejuruan (SMK) yang sudah memiliki bekal keilmuan elektronika dasar dan mikrokontroller untuk diberikan pelatihan pembuatan alat kesehatan dengan mempelajari dan mengembangkan instrumentasi medis sederhana berbasis elektronika dan mikrokontroller sederhana yaitu alat ukur tingkat kelelahan pekerja. Para siswa SMK diharapkan setelah lulus mampu mengembangkan produksi dan pengadaan alat kesehatan secara mandiri di Indonesia. Hasil kegiatan pengabdian masyarakat terlihat bahwa peserta pelatihan sangat antusias terhadap pelaksanaan kegiatan karena mendapatkan pengetahuan baru terkait dasar elektronika dan mikrokontroler.
\end{abstract}

Keywords: Pelatihan; Deteksi kelelahan; Audio visual; Kualitas kerja; Kesehatan.

kerja. Permasalahan utama yang sering dihadapi adalah terjadi kelelahan pekerja yang tanpa disadari yang berdampak hingga membahayakan nyawa para pekerja. International Labour Organization menyampaikan bahwa sebanyak dua juta peserta merenggut nyawa akibat kecelakaan yang

pada kualitas pekerja yang mengakibatkan terjadinya kecelakaan dan penurunan produktivitas 
disebabkan oleh kelelahan tiap tahunnya (Atiqoh, et al., 2014). Di Indonesia sendiri, jumlah kecelakaan kerja mengalami peningkatan tiap tahunnya hingga 5\% (Safitri, 2017). Data dari BPJS Ketenagakerjaan menunjukkan bahwa pada tahun 2016 terjadi 116.850 kasus kecelakaan kerja sedangkan pada tahun 2017 jumlah kasus meningkat 20\%. Sebagian besar penyebab kecelakaan kerja adalah karena unsafe action (tindakan yang kurang memperhatikan keselamatan kerja). Banyak penelitian menunjukkan bahwa kelelahan adalah salah satu faktor yang berkontribusi penyebab kecelakaan, hal ini disebabkan orang yang lelah cenderung bertindak tidak aman. Kajian komprehensif mengenai kecelakaan dilakukan oleh Williamson pada tahun 2011 menunjukan bahwa 5 - $50 \%$ kecelakaan kendaraan berat disebabkan kelelahan (Wiliamson, et al., 2011).

Kelelahan merupakan suatu kondisi yang dialami oleh seseorang setelah melakukan pekerjaan yang berupa perasaan letih, mengantuk, bosan, berkurangnya keseimbangan dan haus. Kelelahan akan menyebabkan penurunan motivasi, kegiatan dan aktivitas fisik. Penurunan motivasi ditunjukkan dengan sulitnya fokus dan berfikir, enggan berbicara, gugup, sulit berkonsentrasi, pelupa, perasaan cemas, kurang percaya diri, sulit mengontrol perilaku, dan tidak rajin dalam melakukan pekerjaan (Ningsih dan Nilamsari, 2018).

Kelelahan yang cukup tinggi bisa disebabkan oleh beberapa faktor, seperti lingkungan yang kurang kondusif, kenyamanan, dan adanya gangguan (Gurusinga, 2013). Masalah tersebut banyak terjadi di industri bidang konveksi kecil atau menengah yang pekerjaannya didominasi oleh gerakan monoton dalam jangka waktu lama (Atiqoh, et al., 2014).

Kasus yang masih hangat di ingatan kita tentang kelelahan kerja adalah banyaknya petugas Komisi Pemilihan Umum (KPU) di daerah yang meninggal dikarenakan kelelahan selama proses Pemilu. Hal ini menunjukkan bahwa pengetahuan mengetahui tingkat kelelahan merupakan hal yang mendesak dan penting untuk diperhatikan. Penyebab utamanya disinyalir adalah penyakit yang berhubungan dengan kelelahan yang disebabkan oleh panjangnya waktu kerja dalm perhitungan kartu suara (Reuters, 2019).

Penyabab utama kelelahan dapat dikelompokkan menjadi dua yaitu, kelelahan fisiologis dan psikologis. Kelelahan fisiologis disebabkan oleh faktor fisik, seperti suhu, penerangan, mikrorganisme, dan kebisingan. Sedangkan kelelahan psikologis disebabkan oleh faktor psikososial seperti tempat kerja, rumah, dan masyarakat (Nurmianto, 2008).

Kelelahan muncul sebagai hasil dari hubungan pekerja yang dilakukan. Jika pekerjaan yang dilakukan telah melebihi batas yang mampu diterima tubuh, maka kelelahan akan cenderung menyerang pekerja. Lamanya masa kerja akan mempengaruhi cepat tidaknya seorang pekerja mengalami kelelahan. Hasil penelitian dari Hermawan dkk. pada tahun 2017 mengungkapkan bahwa ada pengaruh yang signifikan dari masa kerja dengan kelelahan kerja. Semakin lama masa kerja akan meningkatkan risiko bahaya dalam menjalan pekerjaannya (Hermawan, et al., 2017.).

Salah satu cara untuk mencegah kecelakaan kerja adalah dengan mengukur tingkat kelelahan yang dialami pekerja, sehingga dapat diatur beban kerja disesuaikan dengan kapasitas fisik maupun mental pekerja tersebut. Dengan mengetahui tingkat kelelahan, maka pekerja dapat mengatur kapan harus beristirahat agar tidak membahayakan keselamatan dan kesehatannya. Tingkat kelelahan dapat diukur dengan menggunakan prinsip respon refleks terhadap rangsangan yang diberikan, bisa berupa visual maupun audio. Alat deteksi tingkat kelelahan ini mampu memberikan informasi keadaan tubuh seseorang berdasarkan seberapa cepat reflex yang diberikan ketika seseorang menerima rangsangan. Waktu yang dibutuhkan untuk memberikan umpan balik sebagai tanggapan dari rangsangan yang diberikan merupakan parameter utama yang digunakan untuk menentukan tingkat kelelahan yang dialami oleh seseorang.

Berdasarkan uraian latar belakang tersebut dilakukan pelatihan pembuatan alat deteksi kelelahan yang berdasarkan pada refleks audio dan visual. Alat ini diharapkan bisa digunakan oleh masyarakat luas, khususnya pekerja untuk mengurangi risiko kelelahan saat bekerja. Pelatihan pembuatan alat deteksi kelelahan ini dapat diberikan kepada siswa SMK jurusan teknik komputer dan jaringan serta multimedia yang memiliki kemampuan/ketrampilan bidang sistem komputer dan jaringan. Dengan demikian, kegiatan ini nantinya dapat membantu meningkatkan kemampuan entrepreneurship siswa SMK dalam 
membuat alat deteksi kelelahan berdasarkan respon refleks berbasis audio visual.

Wirausaha di bidang alat-alat kesehatan seperti alat deteksi kelelahan ini, seperti memproduksi secara mandiri dan memasarkan alatalat kesehatan di dalam negeri masih sangat sedikit. Pemerintah juga telah melakukan proyeksi pasar alat kesehatan 2014-2019 senilai Rp 7,2 T menjadi Rp. 15,5 T. Disamping itu dengan adanya program Jaminan Kesehatan Nasional (JKN) dari pemerintah, maka kebutuhan alat kesehatan menjadi meningkat dan rumah sakit membutuhkan alat kesehatan dengan harga yang terjangkau (Utomo, 2009). Untuk itulah sangat diperlukan kemandirian bangsa dalam memproduksi alat kesehatan, utamanya untuk kebutuhan sendiri maupun untuk diekspor, sehingga dapat meningkatkan kesehatan dan perekonomian bangsa.

Berdasarkan analisis situasi tersebut, maka melalui kegiatan pengabdian masyarakat Program Kemitraan Masyarakat ini, dapat diberikan bekal keahlian kepada sekelompok masyarakat tertentu yaitu kelompok masyarakat yang memiliki bekal keilmuan tentang elektronika, dalam hal ini yang dapat diberikan pelatihan adalah siswa Sekolah Menengah Kejuruan (SMK). Para siswa SMK diharapkan nantinya setelah lulus mampu mengembangkan produksi dan pengadaan alat kesehatan secara mandiri di Indonesia dalam menghadapi Masyarakat Ekonomi Asean (MEA).

\section{Metode}

Kegiatan pengabdian masyarakat ini melibatkan satu kelompok mitra yang akan diberikan pelatihan pembuatan alat kesehatan deteksi dini kelelahan berbasis audiovisual berbasis mikrokontroller. Kelompok mitra tersebut adalah para siswa SMK 3 Pancasila Ambulu. Adapun tempat pelaksanaan pelatihan adalah di sekolah SMK tersebut, yang berlokasi di Jl. Kopral Soetomo No. 266 Karanganyar, Ambulu, Jember.

Alat yang dibutuhkan dalam kegiatan pengmas ini meliputi: Kit mikrokontroler Arduino Nano dan Osiloskop. Sedangakan Bahan yang dibutuhkan dalam kegiatan pengmas ini meliputi: komponen elektronika penunjang, papan rangkaian elektronik (PCB), dan board trainer.

Program pengabdian kepada masyarakat PKM ini dibagi menjadi dua bagian, yaitu pelatihan elektronika dasar dan mikrontroler dan pelatihan pengaplikasian mikrokontroler pada pembuatan alat deteksi kelelahan. Pada proses pelaksanaan pengabdian kepada masyarakat PKM ini dibantu oleh 4 orang mahasiswa yang memandu para peserta siswa SMK 3 Pancasila Ambulu selama pelatihan berlangsung.

Pelatihan pertama yang diberikan bertema tentang elektronika dasar dan mikrokontroler. Peserta latih diberikan pelatihan tentang dasar-dasar komponen elektronika seperti resistor, kapasitor, operational amplifier dan lain-lain dan juga penggunaannya dengan menggunakan board trainer. Selain itu, peserta latih juga diberikan materi mikrokontroler dan keguaannya di industri. Praktik penggunaan mikrontroler diberikan kepada peserta latih berupa pembuatan sourcecode pada Arduino nano. Pelatihan dasar elektronika dan mikrokontroler ini selanjutnya diterapkan pada pembuatan alat deteksi kelelahan dengan skema rangkaian pada Gambar 1.
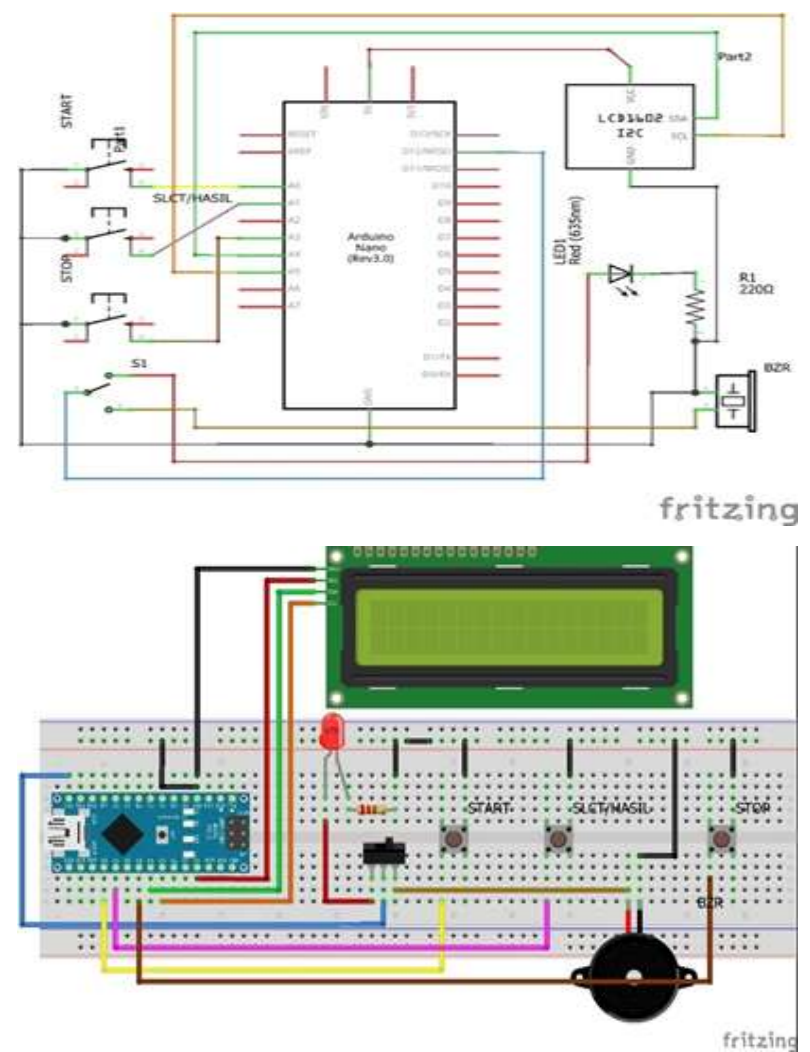

Gambar 1. Skema rangkaian deteksi kelelahan

Proses kegiatan yang dilaksanakan dapat dilihat pada Gambar 3.2. Pembuatan alat kesehatan deteksi kelelahan ini meliputi perancangan software pada Arduino nano yang tujuannya mengatur kedipan cahaya dan suara speaker yang akan dilihat 
dan didengar oleh subyek untuk memberikan respon dari rangsangan cahaya atau suara yang diberikan. Definisi kelelahan dari alat ini ditunjukkan oleh waktu respon subyek. Selanjutnya masing-masing modul diuji kinerjanya berdasarkan linieritas dan stabilitasnya.

Pengguna bisa memilih menggunakan lampu untuk menguji lelahnya mata atau buzzer untuk menguji lelahnya telinga. Mikrokontroller akan menyalakan lampu atau buzzer dengan urutan waktu random. Selanjutnya, pengguna harus menekan tombol atau mouse untuk merespon tiap nyalanya lampu atau suara buzzer. Mikrokontroler akan mencatat selisih waktu antara awal nyalanya lampu atau buzzer dan waktu saat pengguna merespon melalui menekan tombol atau mouse. Aktivitas tersebut berulang dilakukan dan seluruh data waktu akan direkam oleh memori mikrokontroler dan ditampilkan pada LCD.

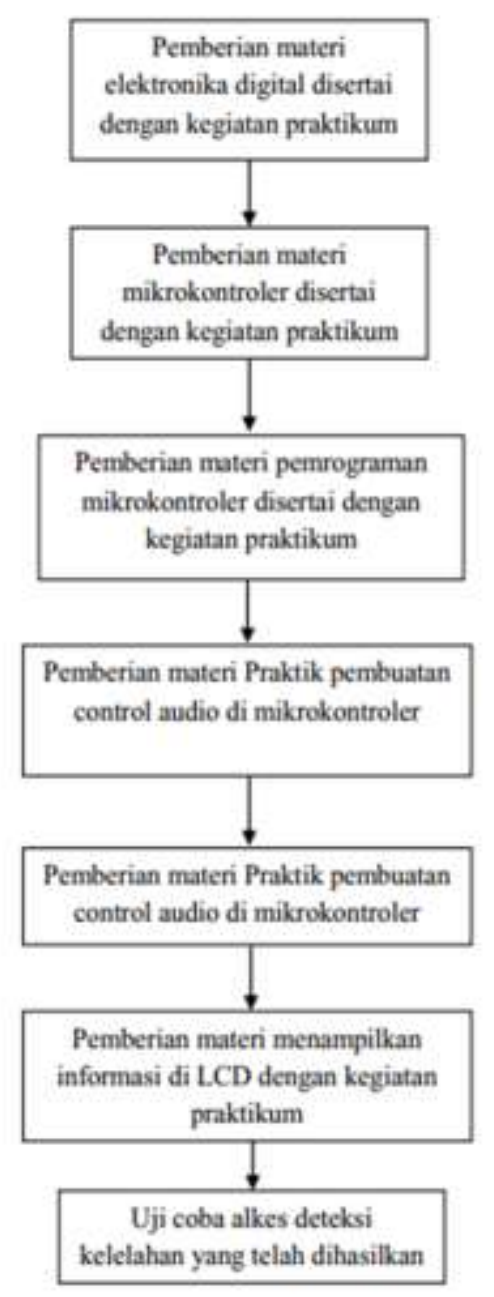

Gambar 2. Metode Pelaksanaan Pelatihan Rancang

\section{Bangun Alat Deteksi Kelelahan}

Pelaksanaan pengmas ini dievaluasi dengan menggunakan sistem kuisioner yang mengukur pengetahuan siswa sebelum dan sesudah pelaksanaan kegiatan terkait materi pelatihan yang telah diberikan. Selain itu, testimoni dari pihak siswa dan guru SMK 3 Pancasila Ambulu juga akan menjadi bahan evaluasi.

\section{Hasil dan Pembahasan}

Kegiatan pengabdian masyarakat pelatihan pembuatan alat deteksi kelelahan ini dilakukan pada tanggal 3 Oktober 2020. Penyampaian materi dilakukan oleh Dr. Prihartini Widiyanti, drg., M.Kes., Erwin Sutanto, S.T., M.Sc., Riries Rulaningtyas, S.T., M.T., dan Franky Chandra Satria Arisgraha, S.T., M.T. dengan tujuan memberikan pemahaman dasar mengenai pandemic COVID-19, dasar elektronika analog, digital dan mikrokontroller.

Kegiatan pengabdian masyarakat dibuka oleh Kepala SMK 3 Pancasila dan ketua pelaksana kegiatan pengabdian kepada masyarakat. Pemberian materi diawali dengan penyampaian pandemic COVID-19 dan juga berbagai kiat yang harus dilakukan untuk menjaga diri dari virus ini. Pemberian materi dilanjutkan dengan materi elektronika dasar, elektronika digital dan mikrokontroller. Pelatihan dilaksanakan tidak hanya dengen sistem ceramah, tetapi juga praktik langsung dengan komponen-komponen elektronika yang sudah ada. Para siswa diberikan latihan soal mengenai dasar elektronika dengan mencoba membaca nilai resistor, kapasitor, dan lain sebagainya.

Setelah mendapatkan pelatihan dasar elektronika analog dan digital, para siswa juga mendapatkan pelatihan mikrokontroler. Berbeda dengan elektronika dasar dan elektronika digital, mikrokontroler belum dikenal siswa SMK, kecuali bagi mereka yang sudah mengenal robotika. Pengenalan dasar mikrokontroler ini bertujuan agar para siswa mengetahui aplikasi elektronika. Salah satunya sebagai sistem deteksi kelelahan. Pelatihan meliputi pengertian mikrokontroler, jenis-jenisnya, bagian-bagiannya dan cara membuat program yang diisikan ke mikrokontroler, meliputi penyusunan kode programnya dengan menggunakan aplikasi Arduino IDE 1.8.3. Latihan yang diberikan kepada 
siswa meliputi membunyikan buzzer dan menyalakan LED dengan input berupa tombol push button yang hasilnya ditampilkan ke LCD.

Para siswa sangat antusias pada pelatihan elektronika dasar dan mikrokontroler ini, karena tidak hanya belajar teori, namun juga melakukan praktikum. Semua peserta ikut aktif dalam proses

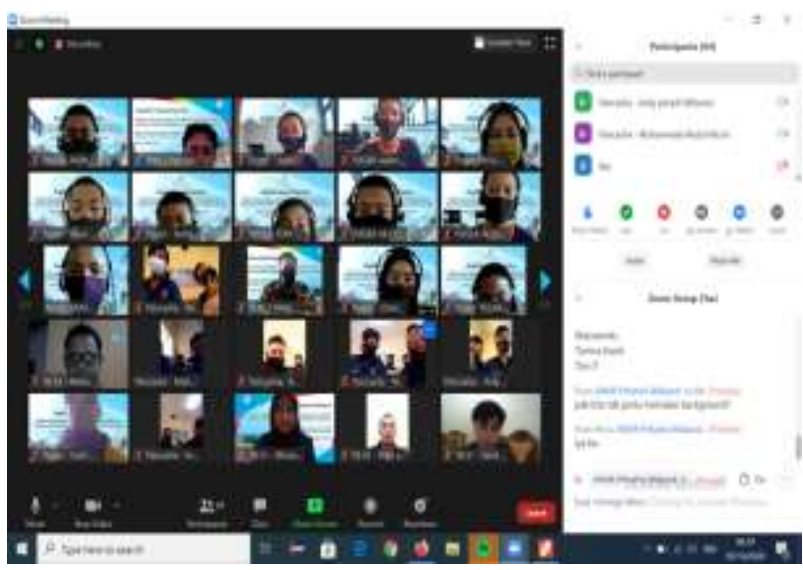

Gambar 3. Penyampaian materi yang dilaksanakan secara daring.

Evaluasi dilakukan dengan memberikan kuisioner kepada para peserta. Hasil kuisioner ini menjadi tolak ukur keberhasilan kegiatan pengmas. Kuisioner mengukur kualitas materi dan narasumber, manajemen dan organisasi, fasilitas dan dukungan unit kerja terhadap pelaksanaan kegiatan. Sebagian besar peserta mengungkapkan bahwa kegiatan pengabdian kepada masyarakat ini pelatihan, mulai dari memberikan pertanyaan maupun dalam melakukan percobaan. Pada umumnya siswa SMK belum memperoleh praktikum elektronika apalagi praktikum mikrokontroler. Pelaksanaan kegiatan pengmas ini ditunjukkan pada Gambar 3 dan Gambar 4.

sangat bermanfaat dan diharapkan keberkelanjutannya.

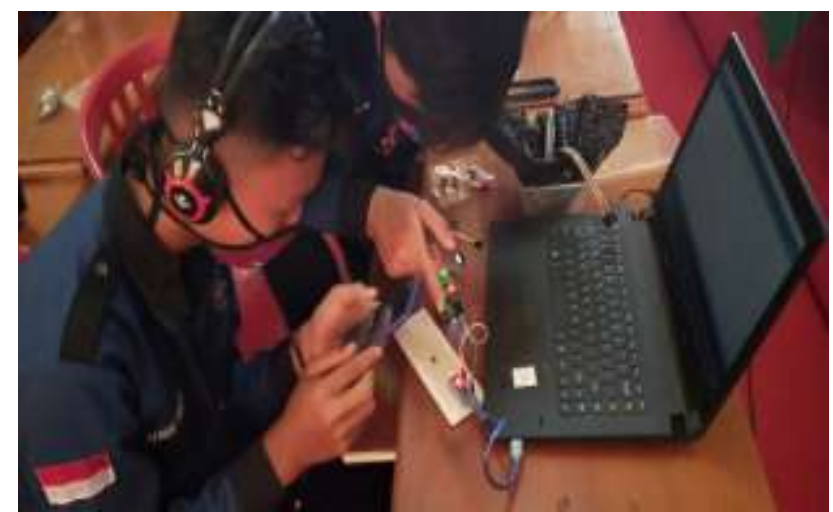

Gambar 4. Siswa sangat antusias saat melaksanakan pelatihan elektronika dan mikrokontroler.

Hasil rekapitulasi kuisioner yang telah diisi oleh peserta pelatihan dapat dilihat pada Tabel 1 . Keterangan yang diberikan pada Tabel 1 merupakan tingkatan jawaban yang diberikan berdasarkan tiap pertanyaan pada kuisioner.

Tabel 1. Rekapitulasi Nilai Kuisioner Peserta Pelatihan

\begin{tabular}{|c|l|c|c|}
\hline No & \multicolumn{1}{|c|}{ URAIAN } & SKOR & KETERANGAN \\
\hline & I. Kualitas Materi dan Nara Sumber & 4.17 & Mutakhir \\
\hline 1 & Kemutakhiran Materi yang disajikan & 4.27 & Sangat Bermanfaat \\
\hline 2 & Kemanfaatan Materi yang diberikan & 4.02 & Memuaskan \\
\hline 3 & Kualitas Penyampaian Materi & 4.15 & Sangat Memuaskan \\
\hline 4 & Kualitas Pendampingan Praktikum/Demo & 4.20 & Tepat \\
\hline & II. Manajemen dan Organisasi & 4.20 & Memadai \\
\hline 5 & $\begin{array}{l}\text { Pemilihan Waktu (hari, tanggal, dan jam) kegiatan yang } \\
\text { tepat }\end{array}$ & 3.90 & Baik \\
\hline 6 & Publikasi/Undangan Kegiatan Yang Memadai & 3.98 & Mudah \\
\hline 7 & Pengaturan Waktu dan Acara Selama Kegiatan & 4.41 & Sangat Memuaskan \\
\hline 8 & Kemudahan Memperoleh Informasi Dari Panitia & \\
\hline 9 & Kualitas Layanan Panitia Selama Kegiatan Pengmas & \multicolumn{2}{l}{} \\
\hline & III. Fasilitas Selama Kegiatan Pengmas &
\end{tabular}




\begin{tabular}{|c|c|c|c|}
\hline 10 & $\begin{array}{l}\text { Ketersediaan Fasilitas Pendukung Selama Kegiatan } \\
\text { Berlangsung }\end{array}$ & 4.29 & Memuaskan \\
\hline 11 & $\begin{array}{l}\text { Ketersediaan Fasilitas Media Pembelajaran (LCD, } \\
\text { Komputer, Peraga, Peralatan Praktikum, dsb.) }\end{array}$ & 4.32 & Memuaskan \\
\hline 12 & Kenyamanan Ruang Kelas/Lab. Yang Digunakan & 4.49 & Nyaman \\
\hline 13 & Ketersediaan Kit Pelatihan & 4.17 & Memuaskan \\
\hline \multirow[t]{2}{*}{14} & Kualitas Konsumsi Yang Disediakan & 4.66 & Sangat Memuaskan \\
\hline & \multicolumn{3}{|c|}{ IV. Dukungan Unit KerjaTerhadap Pelaksanaan Kegiatan Pengmas } \\
\hline 15 & $\begin{array}{l}\text { Sekolah tempat Saudara mengajar/belajar mendukung } \\
\text { kegiatan ini }\end{array}$ & 4.44 & Sangat Mendukung \\
\hline 16 & $\begin{array}{l}\text { Dinas Pendidikan di wilayah Saudara mendukung } \\
\text { kegiatan ini }\end{array}$ & 4.51 & Mendukung \\
\hline
\end{tabular}

Berdasarkan Tabel 1, nampak bahwa sebagian besar peserta pelatihan menjawab dengan poin 4 atau lebih yang berarti memuaskan ketika diberi pertanyaan mengenai kualitas materi dan narasumber, managemen dan organisasi acara, fasilitas selama kegiatan dan dukungan unit kerja terhadap pelaksanaan kegiatan pengabdian masyarakat. Hal ini menunjukkan bahwa material yang disampaikan mampu membuat para siswa tertarik, mudah dipahami, dan meningkatkan wawasan para peserta pelatihan. Selain itu, dari hasil tersebut merepresentasikan bahwa pembawa materi mampu menyampaikan materi dengan baik dan benar sesuai dengan target yang telah ditentukan di awal. Adanya praktik yang diberikan kepada para peserta mampu meningkatkan pemahaman peserta pelatihan terhadap materi yang telah diberikan. Suasana pelatihan yang kondusif didukung dengan aktifnya peserta dalam tanya jawab mampu menghidupkan suasana kelas. Hal ini ditunjukkan dengan nilai hasil kuisioner yang berkaitan dengan fasilitas selama kegiatan pengabdian kepada masyarakat dengan hasil memuaskan (nilai lebih dari 4). Sebagain besar peserta memberikan nilai yang sedang dalam hal pemilihan waktu kegiatan dan memperoleh informasi dari panitia (nilai di bawah 4). Hal ini menjadi bahan evaluasi untuk kegiatan pengabdian kepada masyarakat tahun selanjutnya untuk lebih memperhitungkan waktu pelaksanaan kegiatan. Jadwal pelatihan sebenarnya sudah sesuai dengan jadwal yang direncanakan, tetapi terkait waktu pelatihan yang bersamaan dengan jam pelajaran aktif sehingga dirasa kurang efektif. Masukan yang didapatkan dari peserta pelatihan merupakan saran- saran yang membangun untuk perbaikan pada acara selanjutnya.

Pelaksanaan pengabdian kepada masyarakat kali ini adalah yang pertama dilakukan secara daring. Meskipun cukup berhasil yang ditandai dengan peserta dapat berperan aktif selama kegiatan, namun pelatihan secara tatap muka

langsung masih menjadi harapan semua peserta. Secara umum, hasil dari pelaksanaan kegiatan pengabdian kepada masyarakat ini berjalan dengan lancar, sangat memuaskan dan diharapkan dapat berkelanjutan.

\section{Kesimpulan}

Dari pelaksanaan kegiatan ini dapat disimpulkan bahwa peserta pelatihan sangat antusias terhadap pelaksanaan kegiatan karena mendapatkan pengetahuan baru terkait dasar elektronika dan mikrokontroler sehingga berhasil membuat perangkat pengukur tingkat kelelahan pekerja untuk mendukung kemandirian bangsa terhadap alat kesehatan.

Sedangkan saran untuk kegiatan pengabdian kepada masyarakat di tahun selanjutnya adalah ditingkatkannya program pengabdian kepada masyarakt hingga pengaplikasian hasil serta peningkatan jumlah peserta pelatihan dengan topik yang lebih aplikatif. Pelatihan pengmas ini sebaiknya dilaksanakan secara luring dengan durasi praktik lebih panjang untuk memberi kesempatan siswa SMK mencerna materi pengmas yang diberikan. 


\section{Ucapan Terima Kasih}

Ucapan terima kasih kami sampaikan kepada Fakultas Sains dan Teknologi Universitas Airlangga yang telah memberikan pendanaan melalui Dana Rencana Kegiatan Anggaran Tahunan (RKAT) 2020 dengan Nomor 2681/UN3.1.8/PM/2020 Tanggal 1 Juli 2020 untuk kegiatan pengabdian masyarakat ini.

\section{Daftar Pustaka}

Anaya, Arianti. 2016, Impementasi regulasi izin edar alkes dan dukungan pengadaan alkes dalam negeri, Direktur Penilaian Alat Kesehatan dan PKRT, Kementrian Kesehatan Republik Indonesia.

Atiqoh, J. et al., 2014. Faktor-Faktor yang Berhubungan dengan Kelelahan Kerja pada Pekerja Konveksi Bagian Penjahitan di CV. Aneka Garment Gunungpati Semarang. Jurnal Kesehatan Masyarakat (e-Journal), Vol. 2, No. 2, pp. 119-126.

Gurusinga. 2013, Perbedaan Kelelahan Tanpa dan Dengan Air Minum dan Pisang Ambon pada Pekerja Pabrik Tahu Mrican Semarang. Skripsi. Semarang: Universitas Diponegoro.

Hermawan, B. et al., 2017. Sikap, beban kerja dan kelelahan kerja pada pekerja pabrik produksi aluminium di Yogyakarta. Berita Kedokteran Masyarakat (BKM Journal of Community Medicine and Public Health), Vol. 33, No. 4, pp. 213-218.

Ningsih, S. N. P. dan Nilamsari, N., 2018, Faktor yang berhubungan dengan Kelelahan pada Pekerja Dipo Lokomotif PT. Kereta Api Indonesia (Persero). Journal of Industrial Hygiene and Occupational, Health. Vol. 3, No. 1, pp. 69-82.

Nurmianto, E. 2008. Ergonomi konsep dasar dan aplikasi. Surabaya: PT. Guna Widya.

Reuters, 2019, Indonesia election worker deaths linked to fatigue-related illnesses, nbcnews.com. diakses pada tanggal 24 Maret 2020.

Safitri, M. 2017, Hubungan Beban Kerja dengan Kelelahan Kerja pada Pekerja Industri Rumah Tangga Rambak Kering Desa Doplang Kecamatan Teras Boyolali.
Skripsi. Surakarta: Universitas Muhammadiyah Surakarta.

Utomo, F. H., 2009, Arahan Pengembangan Sekolah Menengah Kejuruan Bisnis dan Manajemen Berbasis Sektor Perdagangan di Kabupaten Tulungagung. Tesis. Surabaya: Institut Teknologi Sepuluh Nopember.

Williamson, A. et al., 2011, The link between fatigue and safety. Accident Analysis and Prevention, 43 (February), pp.498-515. 